\title{
IT outsourcing development trends
}

\author{
Svetlana Fedorova* \\ Irkutsk National Research Technical University, Irkutsk, Russia
}

\begin{abstract}
IT outsourcing is one of the new types of outsourcing. One of the current trends is the use of IT instead of other types of outsourcing. IT outsourcing implies the maintenance of the entire information infrastructure of a company (or individual components) by a third-party company, which specializes in these processes. This is a refusal to hire information technology specialists. There is no universal classification of IT outsourcing services. Several types of IT outsourcing can be distinguished: external and internal; resource and functional; outsourcing of IT infrastructure, IT processes or full outsourcing; disposable and long-term; main and additional. The IT outsourcing has a number of advantages: financial savings, the ability to engage in specialized activities, professional services, promptness of implementation of new technologies. IT outsourcing has some disadvantages: data security, trade secrets, and poor-quality services. Before using IT outsourcing services, a company should analyze business processes, determine the economic efficiency, and conclude a contract.
\end{abstract}

\section{Introduction}

One of the most popular areas in the IT outsourcing is financial. During the crisis, outsourcing helps to maintain the proper level, market positions and control expenditures. The main driver of the IT outsourcing is a desire of banks to reduce costs. This need exists and is constantly growing, especially with the development of payment services [1]. An additional trigger is the financial crisis as a factor requiring critical cost cutting. The transfer of IT functions to an outsourcing company is based on the desire of banks to optimize their businesses [2]. External technical support helps to provide professional services. The quality of services provided is regulated by contracts, and the outsourcing company is responsible for the services provided [3]. Application software development is the most typical IT function that is outsourced to banks. Many financial institutions outsource support for the hardware. A typical example is the service of ATMs [4]. The main reason for the growth of IT outsourcing in the banking sector is the high cost of in-house developments. It is necessary to have developers, task managers, testers, technical writers. The lack of standardization, mistrust of suppliers, immaturity of the market and unwillingness of customers to use outsourcing schemes have negative effects. The main obstacles are the extremely tough position of banking security departments and high requirements for the reliability of IT service providers [5].

\footnotetext{
*Corresponding author: fsta65@yandex.ru
} 
There are three main IT outsourcing models in modern banks. The most standard model is when a developer (an IT outsourcer) offers a ready-made software solution. In this case, a purchase and solution implementation agreement is concluded. At the next stage of outsourcing, bank employees and an outsourcing company install the software.

The second model is as follows: a company is hired to perform certain banking tasks. They develop a product to meet bank's requirements [6].

There is one more outsourcing model, which is quite radical. The developer supports the software developed for the bank. In this case, there is no bank support, and users directly contact the outsourcing company. At the same time, the software is often located on the servers or territory of the outsourcer.

\section{Materials and methods}

There are three main IT outsourcing models in modern banks. The most standard model is when a developer (an IT outsourcer) offers a ready-made software solution. In this case, a purchase and solution implementation agreement is concluded. At the next stage of outsourcing, bank employees and an outsourcing company install the software.

The second model is as follows: a company is hired to perform certain banking tasks. They develop a product to meet bank's requirements [6].

There is one more outsourcing model, which is quite radical. The developer supports the software developed for the bank. In this case, there is no bank support, and users directly contact the outsourcing company. At the same time, the software is often located on the servers or territory of the outsourcer.

\section{Experimental section}

The leader in IT financial outsourcing projects is MAYKOR. Bank Otkrytie". MAYKOR's key customers in the financial sector are the national banks Sberbank, B\&N Bank, Rosselkhozbank, Otkrytie Bank. The Bank Otkrytie offers a wide range of financial services to individuals and corporate clients. It has been included in the TOP-30 Russian banks by their assets. It is extremely important for a retail bank to be represented as widely as possible [7]. This increases its recognition and makes it possible to offer financial products and services to a larger number of clients. At the end of 2012, Bank Otkrytie decided to create a network of mini-offices as part of its regional development strategy. Such sale points do not require time and financial expenses, and they do not differ from traditional branches. In 2013, it was announced that NOMOS-BANK and Bank Petrokommerts were integrated into the FC Otkrytie. The network is developing rapidly and has more than 300 mini-offices [8].

As for such an instant, lightning-fast growth, it is impossible to provide its support. To do this, the bank needs to have about 100 reserve employees [9]. The IT department should focus on the unique expertise, knowledge and experience. That is why Otkrytie Bank turned to the outsourcing services. The MAYKOR company helps the bank to maintain the IT infrastructure of the network in all regions. The bank's first contract with MAYKOR was signed in 2013. Otkrytie Bank uses a scheme for calculating the load on each employee in the regions. The bank provides all this information to the partner to calculate the cost. The key advantage is the ability to open branches in any region. For a retail bank, this is an important criterion for choosing a partner. Working with an outsourcer is financially efficient. The savings are about $40 \%$. Today, together with MAYKOR, Otkrytie Bank is changing the front-system, CRM, and developing anti-fraud technologies [10].

The public sector. The undisputed leader among the consumers of IT outsourcing services in Russia is the public sector, since it is the least flexible in making decisions on the 
development, support and management of its own IT infrastructure and does not have a sufficient number of specialists [11]. Against this background, government agencies are developing large-scale IT programs, and cooperating with IT outsourcers to improve life safety and digitalization of social infrastructure in the public sector: IT infrastructure maintenance, support of systems and applications, storage of documents and data [12].

It should be borne in mind that government agencies often play a key role in the IT market, acting as the largest customers in many areas. The strong positions of the public sector in the IT market are confirmed by both analytical studies and experience of large players: the tasks that the government sets for IT developers and providers are becoming much more complicated, and their scale is growing [13]. The development of an electronic state, the creation of interdepartmental interaction systems and a national cloud platform are projects in which key departments are involved, and their result will directly affect the quality of life of all Russians, not only government officials [14]. The public sector is increasingly outsourcing internal IT functions to third-party companies. This area is growing and will grow even more dynamically. At the same time, customers are becoming more and more mature, optimizing their structure, focusing resources on managers rather than engineers [15]. Thus, on the one hand, the outsourcing market is expanding, and on the other hand, new, much more stringent requirements are imposed on service providers.

\section{Results and discussion}

Education. MAYKOR provides solutions to a wide range of tasks to maintain the efficiency of Gazprom. Within the long-term cooperation, MAYKOR

1. design and modernize data transmission network nodes at communication facilities and engineering systems for Gazprom transgaz Surgut, Gazprom Transgaz Ufa, Gazprom Transgaz Yekaterinburg and Gazprom Extraction Orenburg;

2. ensures the uninterrupted operation of computer and office equipment, telecommunication equipment, digital duplicators and full-color printing equipment at the Gazprom Transgaz Yugorsk enterprise;

3. maintains printing devices at "Gazprom UGS", "Gazprom Processing" in the YamaloNenets Autonomous District, Khanty-Mansi Autonomous Okrug-Yugra and the Komi Republic;

4. ensures the smooth operation of cash registers at gas stations "Gas-Oil";

5. ensures the uninterrupted operation of banking equipment for the Gazprom Gas Distribution Rostov-on-Don enterprise.

Services are paid on a copy-by-copy basis based on actual print and copy volumes. The price of one copy includes all consumables, spare parts and service works. All printing and copying equipment of the Sosnogorsk gas processing plant in the Komi Republic and the Liquid Hydrocarbons Transportation Department in the Yamalo-Nenets Autonomous District is maintained by outsourcers. MAYKOR specialists ensured continuous availability of printing equipment, performed scheduled preventive maintenance and troubleshooting works, replaced spare parts, installed consumables, provided the consulting support for the users. The print service with a copy-by-copy payment system is one of the most profitable schemes for servicing the printing infrastructure for a customer, as it provides full transparency and predictability of printing costs. Special counters installed on each device allow you to monitor all copies produced, which eliminates the cases of unauthorized printing, overspending of paper and other materials. In addition, the customer saves on costs for equipment malfunctions, storage of consumables and spare parts. MAYKOR provides IT outsourcing services for Gazprom in the Volga, Siberian, Ural, South, and North Caucasian regions.

Transport company KIT. 
Transport company "KIT" delivers groupage cargo in Russia, Kazakhstan and Belarus. The federal geographically distributed company has chosen a single service partner MAYKOR to ensure the uninterrupted operation of the entire fleet of computer and office equipment. The MAYKOR company provides the following services:

1. launches new branches in a short time at optimal costs;

2. ensures the efficient operation of IT equipment, the service life was extended by $73 \%$;

3 . increases the speed of order processing, and customer loyalty.

The "KIT" has been on the market for over 8 years. It survived the crisis years, and became a medium-size company. It carries out regular and urgent deliveries of groupage cargo, including documents and parcels.

Under the fierce competition and strict laws, it is important for the transport industry to choose a right strategy. For the KIT company, the most important aspects are a regional network of offices and constant modernization of information systems. The company records over a thousand applications containing the information about the route, overall dimensions and cargo weight, date and time of transportation, contact details of senders and recipients, etc. Errors are not allowed. Any inaccuracy will severely hit the finances and the reputation of the company. The speed and quality of work depend on the level of information technology used. Since 2012, MAYKOR has been involved in maintaining the uninterrupted operation of KIT, providing comprehensive IT infrastructure services for more than 80 geographically distributed divisions throughout Russia. MAYKOR ensures the stable operation of automated workstations, network and server equipment, office equipment, software, provides the roundthe-clock information and consulting support for users.

Energy and utilities

Today, for energy and utilities enterprises, one of the priority tasks is to ensure comfortable financial conditions for consumers, increase the collection of payments and control the consumption of services. Management of the billing system is a crucial task. MAYKOR provides a full range of IT services to ensure the uninterrupted operation and increase the efficiency of energy and utilities enterprises in all regions of Russia.

MAYKOR helps energy and utilities enterprises to solve the following problems:

1. to improve the quality and reliability of services, modernize the mechanisms of customer servicing in the energy and utilities sector

2. to control assets and make the infrastructure available

3. to improve the efficiency of financial activities, reduce the time for preparing reports

4. to control investment activities, plan investment programs and control their implementation

MAYKOR Business Process Outsourcing (BPO) services:

1. Streaming data processing and document management services

2. Maintenance of accounting and tax accounting, reporting

3. Maintenance of HR records and payroll

MAYKOR services aimed to ensure the efficient operation of companies in the energy sector:

Comprehensive services for automating the management of enterprises in the energy and utilities industry (generation, sales, networks): implementation, development and technical support of business applications. Outsourcing of the IT infrastructure maintenance: monitoring and operation management, scheduled preventive maintenance, diagnostics and troubleshooting, software configuration and updating, provision of components and spare parts, consulting support. Maintenance of the infrastructure and equipment: catering points, offices, warehouses and other premises. Technical operation and maintenance of the engineering infrastructure, development and implementation of energy efficiency programs, latest energy-saving technologies. Support for GLONASS / GPS monitoring and fleet management systems, vehicle monitoring and control. 
Comprehensive service support of the infrastructure and automation of business processes:

Business applications: complex enterprise management systems (EMS), converged billing systems, planning and budgeting systems, investment management systems, maintenance management solutions, customer and supplier relationship management (CSRM) systems, human resource management systems (HRM), analytics and reporting systems, mobile applications IT systems: computer and office equipment, servers and network equipment, corporate data transmission networks, data processing and storage systems, telephony systems, audio and video conferencing, information security systems, innovative service of online management of human resources and service works. Engineering systems: ventilation and air conditioning systems, fire protection systems, cable infrastructure, integrated security systems, water supply and heating systems, power supply and lighting, integrated energy monitoring and accounting systems, automated control and dispatching systems for energy facilities and housing and communal services.

\section{Summary and conclusion}

MAYKOR is the largest company in the Russian IT outsourcing market. The competitive advantages of the company are as follows: availability of its own resources, high quality services, a wide network of 83 branches and 400 local divisions covering the entire territory of Russia, innovativeness.

The company provides a full range of IT outsourcing services: centralization of management, service support and development of the customer's IT infrastructure; maintenance of technical equipment and development of geographically distributed turnkey facilities - offices, branches, warehouses, sale points; transfer of the entire technological infrastructure of client's facilities to a new premises: inventory, installation / dismantling works, reconnection, configuration and testing of systems. MAYKOR also provides cloud spectrum services.

The maintenance of the IT infrastructure and office equipment is one of the main activities of MAYKOR. "Print services" are in great demand. They imply a long-term lease of printing equipment from an outsourcer and payment for each printed page.

Each sector served by the IT outsourcing company has its own characteristics. Some of the most active users of IT outsourcing services are the retail sector, the government agencies, and the financial sector. MAYKOR works with companies from each sector, providing industry-specific IT outsourcing services. Among the major clients of MAYKOR are the Social Insurance Fund of the Russian Federation, Russian Post, Gazprom, Rosneft, Metro, Svyaznoy, etc.

\section{References}

1. A.O. Gelfand, Notes of a scientist 3,26 (2015)

2. Y.I. Gribanov, Improving the efficiency of IT infrastructure system outsourcing services: Thesis (Perm, 2013)

3. E.N. Guseva, Modern technology and technology 6(46), 131 (2015)

4. L.G. Dubitsky, Outsourcing and quality of products and services. View of the problem. Part 1 (Academy of Standardization, Metrology and Certification, 2013)

5. Y.D. Izotova, New science: experience, traditions, innovations 4-1(77), 74 (2016)

6. IT outsourcing. Practical guide (Alpina Books, 2014)

7. R.A. Kashaev, Young scientist 18, 273 (2015)

8. A.Kh. Kurbanov, Outsourcing: history, methodology, practice (INFRA-M, 2014) 
9. F.D. Kurbanova, IT Outsourcing in Russia 2, 199 (2016)

10. Yu.V. Kurylenk, Regional Economy and Management 2(02), 147 (2014)

11. O.S. Lisnevskaya, Scientific Almanac 2-1(16), 218 (2016)

12. I.V. Lukyanov, Modern studies of social problems 4(48), 379 (2015)

13. N.A. Mansurova, Bulletin of TVSU. Economics and Management Series 19, 129 (2014)

14. M.A. Timofeev, Development of tools for the implementation of an innovative project using process control outsourcing: Thesis (2017)

15. A.V. Shalamay, New science: current state and development paths, 3, 173 (2017)

16. N.O. Ergardt, Bulletin of the Institute of Economics of the Russian Academy of Sciences 1, 263 (2011) 